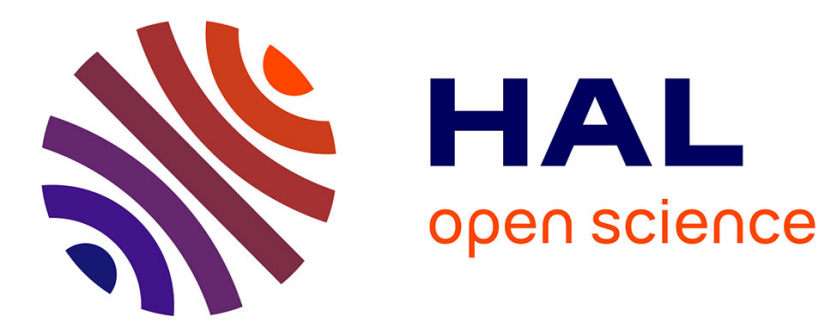

\title{
Entrepreneurship and Rent-Seeking Behavior
}

\author{
Marcus Dejardin
}

\section{To cite this version:}

Marcus Dejardin. Entrepreneurship and Rent-Seeking Behavior. David B. Audretsch, Oliver Falck, Stephan Heblich, Adam Lederer. Handbook of Research on Innovation and Entrepreneurship, Edward Elgar, pp.17-23, 2011. halshs-00616302

\section{HAL Id: halshs-00616302 \\ https://shs.hal.science/halshs-00616302}

Submitted on 22 Aug 2011

HAL is a multi-disciplinary open access archive for the deposit and dissemination of scientific research documents, whether they are published or not. The documents may come from teaching and research institutions in France or abroad, or from public or private research centers.
L'archive ouverte pluridisciplinaire HAL, est destinée au dépôt et à la diffusion de documents scientifiques de niveau recherche, publiés ou non, émanant des établissements d'enseignement et de recherche français ou étrangers, des laboratoires publics ou privés. 


\title{
Entrepreneurship and Rent-Seeking Behavior ${ }^{*}$
}

\author{
Marcus DEJARDIN
}

FUNDP-University of Namur and

Université Catholique de Louvain

January 2011

\begin{abstract}
In this chapter, we propose a primer of the treatment that has received in the economic literature the problematic of entrepreneurship and rent-seeking behavior. It comprises the introduction of employed concepts, the discussion of the allocation of entrepreneurs between different types of economic projects, namely between innovative entrepreneurship and rent-seeking, as well as the explicative factors of the allocation. Interactions between entrepreneurship, rent-seeking and growth are considered (also for a reference situation departing from the first best). Some policy implications are finally briefly evoked.
\end{abstract}

JEL-classification: L26, D70, O10, O40.

Keywords: entrepreneurship, rent-seeking, economic development.

Correspondence address: Marcus Dejardin, Centre de recherches en Economie Régionale et Politique Economique (CERPE), Faculté des Sciences économiques, sociales et de gestion, Facultés Universitaires Notre-Dame de la Paix, Rempart de la Vierge, 8, 5000 Namur, Belgium. E-mail: marcus.dejardin@fundp.ac.be

Acknowledgment: The author thanks Jean-Marie Baland, Pierre Perrin, Margaret Main, Michel Mignolet and Adam Lederer for comments on earlier versions.

\footnotetext{
* Published in D. Audretsch, O. Falck, S. Heblich, A. Lederer, eds (2011), Handbook of Research on Innovation and Entrepreneurship, Cheltenham: Edward Elgar, 17-23.

See http://www.e-elgar.co.uk/bookentry main.lasso?id=13275
} 
Entrepreneurship is now pervasively recognized in economic theory for its contribution in carrying innovation into the economic process and, consequently, in feeding economic growth (Aghion and Howitt, 1992; Carree and Thurik, 2003). Ceteris paribus, different entrepreneurial endowments may explain different rhythms of growth between nations. Among the theoretical discussions of the several conditions entering the ceteris paribus assumption, one appears tremendously fruitful. It relates to the allocation of the entrepreneurial resources between more or less socially productive activities. All activities in a maximizing economy are not equally conducive to production and economic growth. Some can even affect growth negatively. The idea is linked with the concept of rent-seeking behavior. The connections between entrepreneurship and rent-seeking behavior constitute the topic of this chapter.

Having defined the general framework and employed concepts, we shall discuss the allocation of entrepreneurs between different types of economic projects (in other words, between innovative entrepreneurship and rent-seeking), as well as the explicative factors of this allocation. A dynamic set-up follows where interactions between project categories and relations to growth are scanned. We conclude by briefly examining some policy implications.

\section{Introducing entrepreneurship and rent-seeking behavior}

Assuming that the individual arbitrage between different remunerative occupations ends up, in all cases, in the development of socially productive activities, the economy is sketched as a strict income economy. Maximizing individuals exploit their skills as best they can. Moreover, in a perfectly competitive economy, private and social benefits coincide.

Now, let us introduce an activity that is remunerated by transfers. We note that, by definition, transfers do not imply a productive counterpart. Transfers result in the possibility that distortions between private and collective interests may occur. This distortion is undoubtedly effective when rent-seeking is involved when compared with the classical competitive benchmark model. That is, the actual net effects of rent-seeking (whether positive or negative) is a matter of concern since optimal allocation and dynamic efficiency of the economy are not taken for granted, as suggested later on.

Although Tullock introduced the basic argument corresponding to rent-seeking behavior to public choice theory in 1967, the term 'rent-seeking' was not coined until Krueger published 'Political Economy of the Rent-Seeking Society' in the American Economic Review in 1974 (see Tullock, 2003). According to its most common and widespread definition, rent-seeking (behavior) refers to 'the socially costly pursuit of wealth transfers' (Tollison, 1997, p. 506). Rent-seekers' private returns result from redistribution of wealth and not from wealth creation (Murphy et al., 1991).

The rent at stake here is to be distinguished from entrepreneurial creation of rents: rents due to better use of resources, arising from specific assets or technology, securable (by patents, for example) but limited in time from the pressure of competitors and progress (Douhan and Henrekson, 2007; see also Alvarez, 2007; Douhan and Henrekson, 2008a). 
On the other hand, Tollison's definition of rent-seeking allows for an expression of social opportunity costs in terms of resources diversion to, or following, the rent-seeking activity. Examples of rent-seeking include corruption, stealing, bribery, as well as seeking abusive judicial compensation or protection-seeking with the express purpose of limiting economic competition and promoting particular interest. Rent-seeking can originate from both the public and private sectors.

For the connection between entrepreneurship and growth, the occurrence of unproductive but remunerated activities means that not only are projects with socially positive or negative impacts in competition, but also that there is a direct potential diversion of entrepreneurial talents. For this diversion to take place, it is assumed that the skills and abilities required by entrepreneurship and by rent-seeking correspond.

Following these introductory considerations, at least two remarks can be formulated that are considered as important additions. The first refers to public action and public services. The economic rationale for public intervention refers generally to market failures, magnificent evidence-jigging from economic reality and questioning the benchmark of the perfectly competitive model. ${ }^{1}$ Public services are generally financed by transfers. That being the case, transfers are not a sufficient condition for defining rentseeking. Public services are not included in rent-seeking given their socially productive contribution. We note further that, while a discussion of the redistribution role of the state is outside the framework of this chapter, things may appear differently if we look at legal institutions that organize productive activities, as they might, for example, create rent-seeking behaviors by limiting competition.

The second remark concerns the entrepreneurial initiatives and goes back to the entrepreneurial creation of rents through innovation. Through innovation, the entrepreneur seeks to create a monopoly position, from which he will derive overprofit. In the Schumpeterian model, this position is necessary as it motivates the innovation activity. However, it is temporary, as competition will quickly reduce this position in favor of a new monopoly created by a new innovation. The institutional framework of competition is of primary importance. In this case, a dynamic assessment of the entire process will justify the existence of an abnormal profit, as it will distinguish its positive net contribution to the social benefit² ${ }^{2}$

Rent-seeking behavior thus defined, as well as the general framework of this chapter, we address in the following discussion the allocation of talents between socially productive entrepreneurship and rent-seeking or unproductive activities.

\footnotetext{
${ }^{1}$ Observation of reality would not only lead to point market failures but state failures as well, as public choice theorists would note.

2 On this question, see Buchanan (1980).
} 


\section{Explaining the allocation of talents}

Attempting to explain the allocation of talents implies considering a variety of arguments explaining individual arbitrage between distinct remunerative activities. Together with relative remunerations, institutions or non-pecuniary factors may also play a role. According to Murphy et al. (1991, p. 506), 'talent goes into activities with the highest private returns, which need not have the highest social returns'. These authors assume increasing returns on talent. In other words, the greater the ability of an individual, the greater his private benefits will be. Because the exercise of talent is physically limited (by the period of human activity in a day), talented individuals tend to invest themselves and their abilities in reward-maximizing occupations. It follows that their occupational choice is almost directly determined by the size of the market, the compensation contract (rewards on talent application) and the technology.

Furthermore, the allocation of talent can be linked with both institutional context and non-pecuniary explicative factors. The legal framework and its effective use define a propitious environment for entrepreneurship and, contrarily, for rent-seeking behavior. Property rights, the conditions of their application, and the respect of these rights, joined with governance and fiscal organization, appear to be crucial factors. They contribute particularly and decisively to determine compensation schemes. Information is also important as it determines the efficiency of allocation and how far it is possible to link talents' application and its social and economic results (Baumol, 1990 and 1993; Murphy et al., 1991; Acemoglu, 1995; Mohtadi and Roe, 2003; Gradstein, 2004; Corchón, 2008).

Social esteem may play a role. The question therefore becomes how much entrepreneurship is socially valued over other less socially productive occupations (see the seminal Baumol, 1990 and 1993). Finally, entrepreneurs or rent-seekers may influence, by voting or lobbying, political organization and political decisions. The idea is that the political equilibrium, responding to one or another group's interests, will make decisions favoring its maintenance (Acemoglu, 1995). Regarding this last argument, we point out that the innovative entrepreneur would be strongly inclined, when in a (temporary) monopoly position, to adopt rent-seeking behavior.

\section{Entrepreneurship and rent-seeking in motion}

The interaction between entrepreneurship and rent-seeking is an interesting question to examine. Formalized models show that multiple equilibria - an equilibrium being defined by an entrepreneur share in the population and a rate of growth - may exist (Murphy et al., 1993; Acemoglu, 1995; Mehlum et al., 2003a, 2003b). Readers interested in model developments may consult the above references. To give a brief overview, we note that results may be derived from the specification of two functions, both with negative slopes, and consequently the potential for multiple intersections. Because it places burdens on entrepreneurial rewards, rent-seeking negatively affects entrepreneurship. Moreover, given competition in the rent-seeking sector itself, ${ }^{3}$ rent-

\footnotetext{
${ }^{3}$ Acemoglu (1995, p. 29) discusses the case when barriers to entry in rent-seeking activities are established by insiders.
} 
seeking rewards will depend negatively on the number of rent-seekers. Baland and Francois (2000) formalize the effect of entrepreneurial activities on rent-seeking. Their model applies to an economy with import licenses. The production of direct substitutes by local entrepreneurs tends to limit the rents obtained by importers. Results suggest the existence of multiple equilibria. Additionally, these authors discuss the effect of an exogenous resource boom such as an increase in income resulting from an increase in the world price of exports. In their model, the result, more entrepreneurship or more rent-seeking, depends on the importance of the proportion of entrepreneurs and rentseekers in the population preceding the shock.

Lane and Tornell (1996) initiate an important and often connected literature with the introduction of the 'voracity effect', which is 'a more than proportional increase in aggregate redistribution in response to an increase in the raw rate of return' (p. 226). Recent contributions, also related to the 'natural resource curse', include those by Torvik (2002), Mehlum et al. (2006), Perroni and Proto (2009), and Do and Levchenko (2009). For the sake of illustration, Tornell and Lane (1999) analyze the consequences of windfall gains in a two-sector economy. The first sector can be taxed, the second cannot. Moreover, the first sector uses more efficient technology than the second. Weak legal and political institutions as well as the existence of powerful lobbies characterize the economy. Each tries to support their own interests in an effort to increase their share of the national wealth through additional transfers. This leads to higher tax rates, where they can be applied, i.e. in the first sector. This provokes the reallocation of production factors toward the non-taxed and less productive sector. The result, the so-called voracity effect, is that a positive exogenous shock is followed by a more than proportional increase in transfers and a decline in growth.

Rent-seeking behavior may affect entrepreneurial activities and innovation. Several contributions can be found modeling the relationships. Recent contributions include Acemoglu and Robinson (2006a), and Chaudhry and Garner (2007). A simple, nonformalized but clear-cut discussion of the problem is proposed by Murphy et al. (1993, pp. 412-13). These authors suggest that rent-seeking, whether from private or public origins, can undoubtedly jeopardize the profits of established productive sectors. The innovation sector, however, might be described as the reserved hunting ground of public rent-seeking. In particular, their arguments rely on the nature of innovation. While the project develops, the innovative entrepreneur is confronted with legal and environmental constraints. Innovation may need production permits, licenses, dispensations, as well as amendment to local zoning regulations. This results in demand for government intervention and provides opportunities for corruption. Moreover, the socially unproductive transfers that corruption implies may inhibit some innovative activity, given that innovators may not have equal lobbying power compared to that of established firms, or the same financial resources to pay bribes. To avoid expropriation, important funds are then consumed instead of invested. The ex post existence of rentseeking should increase project risk and effective cost. The authors mention, following these arguments, that the negative effects of rent-seeking could be limited if the rentseeker became a stakeholder in the innovation project. In the long run, rent-seekers should be interested in such involvement. This idea can be generalized as: rent-seeking, 
by jeopardizing current entrepreneurial profits, limits its future transfer opportunities. See Mehlum et al. (2003b).

The interaction between entrepreneurship and rent-seeking can generate multiple equilibria that correspond to an allocation of talents and an economic growth rate. Starting from a dynamic extension of his basic model, Acemoglu (1995) discusses the history dependence of an economy. 4 Past and current allocation of talents influences the future structure of rewards. Given historical circumstances (particularly describing successive states of determining factors and allocation), the economy can be locked in low or high steady-state equilibrium. The extremes are high rent-seeking with low growth rate versus highly active and socially productive entrepreneurship with high growth rate. Under these circumstances, for economies trapped in inferior equilibrium, it seems that only an exogenous shock will have any positive and sustainable effect.

That being the case, if rent-seeking affects innovation and economic growth, the actual net effects of rent-seeking are not always as clear as the above cited literature on rentseeking suggests. One may expect the effects to be obviously negative. But rent-seeking should also be discussed in comparison with a reference situation that could be far from the benchmark of the perfectly competitive model. In some circumstances - for a reference situation that is not the first best but could be more comparable with the actual situation of a given jurisdiction, the net effects could be positive, as has been suggested by some authors (Samuels and Mercuro, 1984; Douhan and Henrekson, 2007). Distorted allocation may render rent-seeking necessary to attain greater efficiency. For example, accepting the rent-seeking behavior of some official (or even taking it as an opportunity) and bearing the cost of bribery may sometimes be the only way for an entrepreneur to make concrete efficiency-enhancing innovation. Both from a private and a social viewpoint, efficiency gains can be greater than the rent-seeking costs - and achieving the new situation would be impossible without accepting rent-seeking.

\section{Entrepreneurship, rent-seeking and public policy}

The allocation of entrepreneurial supply between socially productive and unproductive, or rent-seeking, projects relies on an arbitrage. The result contributes to determining economic growth. In contrast to entrepreneurial supply, which is ultimately explained by the distribution of skills and abilities in the population and on which it is difficult to intervene, the allocation presents some opportunities for public actions (Baumol, 1990, 1993; Naudé, 2008). It could, for example, take the form of (additional) fiscal measures in favor of innovation rewards. Another way could consist in (heavier) penalties on socially unproductive activities. Dutz et al. (2000), referring more particularly to economies that are developing or in transition, and Minniti (2008) stress the primordial role that could be played by governments in creating (or reinforcing) institutions that foster entrepreneurship. An emphasis on better institutions and regulation can be included in a more general framework helping to define entrepreneurial policy guidelines (see Audretsch et al. 2007).

${ }^{4}$ Also see some more recent contributions: Acemoglu et al. (2005), Acemoglu and Robinson (2006b), Douhan and Henrekson (2008b). 


\section{References}

ACEMOGLU, D. (1995), 'Reward structures and the allocation of talent', European Economic Review, 39, 17-33.

ACEMOGLU, D. and J. A. ROBINSON (2006a), 'Economic backwardness in political perspective', American Political Science Review, 100, 1, 115-131.

ACEMOGLU, D. and J. A. ROBINSON (2006b), 'Persistence of power, elites and institutions', American Economic Review, 98(1), 267-293.

ACEMOGLU, D., JOHNSON, S. and J. A. ROBINSON (2005), 'Institutions as the fundamental cause of long-run growth', in: P. AGHION and S. DURLAUF, eds., Handbook of Economic Growth, Amsterdam: North-Holland, 385-472.

AGHION, P. and P. HOWITT (1992), 'A model of growth through creative destruction', Econometrica, 60, 2, 323-351.

ALVAREZ, S. A. (2007), 'Entrepreneurial rents and the theory of the firm', Journal of Business Venturing, 22, 3, 427-442.

AUDRETSCH, D.B., GRILO, I. and A.R. THURIK (2007), 'Explaining entrepreneurship and the role of policy: a framework', in: D.B. AUDRETSCH, I. GRILO and A.R. THURIK, Handbook of Research on Entrepreneurship Policy, Cheltenham: Edward Elgar, 1-17.

BALAND, J.-M. and P. FRANCOIS (2000), 'Rent-seeking and resource booms', Journal of Development Economics, 61 (2), 527-542.

BAUMOL, W.J. (1990), 'Entrepreneurship: productive, unproductive, and destructive', Journal of Political Economy, 98, 5(1), 893-921.

BAUMOL, W.J. (1993), Entrepreneurship, management, and the structure of payoffs, Cambridge, Massachusetts: MIT Press.

BUCHANAN, J.M. (1980), 'Rent seeking and profit seeking', in J.M. BUCHANAN, R.D. TOLLISON and G. TULLOCK, ed., Toward a theory of the rent-seeking society, College Station: Texas A\&M University Press, 3-15. [Reprinted in The economic analysis of rent seeking, ed. R.D. CONGLETON and R.D. TOLLISON, The International Library of Critical Writings in Economics, 49, Aldershot: Edward Elgar, 1995, 46-58.]

CARREE, M.A., THURIK, A.R. (2003), 'The impact of entrepreneurship on economic growth', in: D.B. AUDRETSCH and Z.J. ACS, eds, Handbook of Entrepreneurship Research, Dordrecht: Kluwer Academic Publishers, 437-471.

CHAUDHRY, A. and P. GARNER (2007), 'Do Governments Suppress Growth?: Institutions, Rent-Seeking, and Innovation Blocking in a Model of Schumpeterian Growth', Economics and Politics, 19, 1, 35-52.

CORCHÓN, L.C. (2008), 'Forms of governance and the size of rent-seeking', Social Choice and Welfare, 30, 2, 197-210.

DO, Q.-T. and A.A. LEVCHENKO (2009), 'Trade, inequality, and the political economy of institutions', Journal of Economic Theory, 144, 1489-1520. 
DOUHAN, R. and M. HENREKSON (2007), 'The political economy of entrepreneurship', Working Paper Series 716, Research Institute of Industrial Economics. DOUHAN, R. and M. HENREKSON (2008a), 'The political economy of entrepreneurship: An introduction', in HENREKSON, M. and R. DOUHAN, eds., The Political Economy of Entrepreneurship Vol. I and II. The International Library of Entrepreneurship 11. Cheltenham: Edward Elgar, xi-xxxi.

DOUHAN, R. and M. HENREKSON (2008b), 'Productive and Destructive Entrepreneurship in a Political Economy Framework', Working Paper Series 761, Research Institute of Industrial Economics.

DUTZ, M.A., J.A. ORDOVER and R.D. WILLIG (2000), 'Entrepreneurship, access policy and economic development: lessons from industrial organization', European Economic Review, 44, 739-747.

GRADSTEIN, M. (2004), 'Governance and growth', Journal of Development Economics, 73, $2,505-518$.

KRUEGER, A. (1974), 'The Political Economy of the Rent-Seeking Society', American Economic Review, 64, 3, 291-303.

LANE, P.R. and A. TORNELL (1996), 'Power, growth, and the voracity effect', Journal of Economic Growth, 1, 213-241.

MEHLUM, H., MOENE, K.O. and R. TORVIK (2003a), 'Predator or prey? Parasitic enterprises in economic development', European Economic Review, 47, 2, 275-294.

MEHLUM, H., MOENE, K.O. and R. TORVIK (2003b), 'Destructive creativity', Nordic Journal of Political Economy, 29, 77-84.

MEHLUM, H., MOENE, K.O. and R. TORVIK (2006), 'Institutions and the resource curse', Economic Journal, 116, 1-20. [Reprinted in 40 Years of Research on Rent Seeking, eds R.D. CONGLETON, A.L. HILLMAN and K.A. KONRAD, Volume 2. Berlin: Springer, 245-264].

MINNITI, M. (2008), 'The role of government policy on entrepreneurial activity: productive, unproductive, or destructive?', Entrepreneurship Theory and Practice, 32, 5, 779-790.

MOHTADI, H., ROE, T. (2003), 'Democracy, rent-seeking, public spending and growth', Journal of Public Economics, 87, 3-4, 445-466.

MURPHY, K.M., SHLEIFER, A. and R.W. VISHNY (1991), 'The allocation of talent: implications for growth', The Quaterly Journal of Economics, CVI, May, 503-530.

MURPHY, K.M., SHLEIFER, A. and R.W. VISHNY (1993), ‘Why is rent-seeking so costly to growth?', American Economic Review, Papers and Proceedings, May, 409-414.

NAUDÉ, W. (2008), 'Entrepreneurship in Economic Development', UNU-WIDER Research Paper No. 2008-20.

PERRONI, C. and E. PROTO (2009), 'Entrepreneurial drain under moral hazard: A highyield sector curse?', Journal of Development Economics, forthcoming [available online first]. 
SAMUELS, W.J. and N. MERCURO (1984), 'A critique of rent-seeking theory', in: D.C. COLANDER, ed., Neoclassical political economy, Cambridge (Mass.): Ballinger, 57-70.

TOLLISON, R.D. (1997), 'Rent seeking', in: D.C. MUELLER, ed., Perspectives on public choice, Cambridge: Cambridge University Press, 506-525.

TORNELL, A. and P.R. LANE (1999), 'The voracity effect', American Economic Review, 89, $1,22-46$.

TORVIK, R. (2002), 'Natural resources, rent seeking and welfare', Journal of Development Economics, 67, 2, 455-470.

TULLOCK, G. (1967), 'The welfare costs on tariffs, monopolies, and theft', Western Economic Journal, 5, June, 224-232. [Reprinted in R.D. CONGLETON and R.D. TOLLISON, eds, The economic analysis of rent seeking, The International Library of Critical Writings in Economics, 49, Aldershot: Edward Elgar, 1995, 3-11.]

TULLOCK, G. (2003), 'The origin rent-seeking concept', International Journal of Business and Economics, 2, 1, 1-8. 